Lauris Rasnačs, Dr. iur.

University of Latvia, Latvia

\title{
POTENTIAL IMPROVEMENTS IN THE LAWS OF THE REPUBLIC OF LATVIA CONCERNING THE PROTECTION OF THE TRADE SECRETS
}

\section{POTENCIĀLIE UZLABOJUMI LATVIJAS \\ REPUBLIKAS KOMERCNOSLËPUMU AIZSARDZĪBAS LIKUMDOŠANĀ}

\begin{abstract}
Kopsavilkums
Lai gan 2019. gada 1. aprìlī Latvijā ir stājies spēkā jauns Komercnoslēpumu aizsardzības likums, ar ko ieviesta Eiropas Parlamenta un Padomes 2016. gada 8. jūnija Direktīva Nr. 2016/943 par zinātības un darījumdarbības neizpaužamas informācijas (komercnoslēpumu) aizsardzību pret nelikumīgu iegūšanu, izmantošanu un izpaušanu (Komercnoslēpumu direktīva), vairāki svarīgi komercnoslēpumu aizsardzības aspekti Latvijā joprojām nav atrisināti. To vidū ir pirmslīgumiskā atbildība par komercnoslēpumu neatļautu izmantošanu, juridisko instrumentu uzlabošana, sniedzot atbildi, vai noteikta informācija uzskatāma par komercnoslēpumu, kā arī cēloṇsakarības un zaudējumu apmēra novērtējums komercnoslēpumu aizskāruma gadījumā. Tādē šì raksta mērḳis ir apskatīi minētos aspektus un sniegt priekšlikumus to regulējuma uzlabojumiem.
\end{abstract}

Atslēgvārdi: komercnoslēpumi, izgudrojumi, intelektuālais īpašums, īpašas deliktu tiesības

\begin{abstract}
Summary
Despite the fact, that on 1 April, 2019 Latvia has introduced the new Latvian Business Secret Protection Act (Komercnoslēpuma aizsardzības likums - lv.; Business Secret Protection Act $)^{1}$, which does reflect various aspects, addressed to EU Member States by Directive (EU) 2016/943 of the European Parliament and of the Council of 8 June 2016 on the protection of undisclosed know-how and business information (trade secrets) against their unlawful acquisition, use and disclosure (Trade Secrets Directive), ${ }^{2}$ several important aspects regarding the protection of the trade secrets in Latvia yet remains uncovered. Among such uncovered aspects could be mentioned pre-contractual liability regarding the unauthorized use of trade secrets, improvements in legal instruments, giving the answer, whether certain information shall be treated as the trade secret, as well as the assessment of causality and amount of damages in case of infringement of the trade secrets. Hence the purpose of this article is to examine these aspects and to provide proposals on the improvements of their regulation.
\end{abstract}

Keywords: trade secrets, inventions, intellectual property, specific tort law

Komercnoslēpuma aizsardzības likums (Business Secret Protection Act): LV Likums. Latvijas Vēstnesis, 14.03.2019., Nr. 52 (6391).

2 Directive (EU) 2016/943 of the European Parliament and of the Council of 8 June 2016 on the protection of undisclosed know-how and business information (trade secrets) against their unlawful acquisition, use and disclosure. OJ L 157, 15.6.2016, pp. 1-18. 


\section{Introduction}

As it is provided in the summary, the purpose of the present article is to analyse several aspects, which are important for the protection of trade secrets, but are not yet covered by the provisions of newly adopted Business Secret Protection Act and in the result of this analysis to provide proposals, how these aspects shall be regulated, understood or covered. Beside the fact that the author within the said analysis has used various theorethical materials, the main target, however, is to provide the above-mentioned proposals with practical value. Therefore, the present article may be interesting not only to legal scholars, but also to the legal practitioners, businessman, inventors and other persons dealing with protection of trade secrets in actual circumstances.

\section{Remarks on meaning of the trade secret and its holder}

Despite the fact, that the legal term 'trade secret' (or business secret) is used in numerous legal acts and several jurisdictions, no one has actually dared to give an explicit and exhaustive definition of the trade secret. Article 39 and other articles of Section 7 of the Agreement on Trade-Related Aspects of Intellectual Property Rights (TRIPS Agreement) simply uses the term 'undisclosed information' without further explanations. ${ }^{3}$ Trade Secrets Directive in paragraph 1, Article 2 gives rather descriptive definition, namely: "'trade secret' means information which meets all of the following requirements (a) it is secret in the sense that it is not, as a body or in the precise configuration and assembly of its components, generally known among or readily accessible to persons within the circles that normally deal with the kind of information in question; (b) it has commercial value, because it is secret; (c) it has been subject to reasonable steps under circumstances, by the person lawfully in control of


Secret Protection Act, paragraph 1, Article 2, which basically does correspond to the earlier definition given in the paragraph 1 , Article 19 of Latvian Commercial Law. ${ }^{5}$ Such descriptive definitions mean than in all cases of disputes the parties will have to provide argumentation or to argue and the court will have to examine, whether the particular information, alleged to be the trade secret, possess all three particularities making it a trade secret. Conclusions in each particular case may differ, however, one shall keep in mind also the examples (clearly, not of exhaustive nature), given in the legal doctrine and indicating what kind of information may be treated as trade secrets. Notable British IP legal scholars Cornish and Llewelyn propose that trade secrets may

Agreement on Trade-Related Aspects of Intellectual Property Rights. Annex 1C of the Marrakesh Agreement Establishing the World Trade Organisation, signed on 15 April, 1994. International Agreement.

4 Directive (EU) 2016/943 of the European Parliament and of the Council of 8 June 2016 on the protection of undisclosed know-how and business information (trade secrets) against their unlawful acquisition, use and disclosure. OJ L 157, 15.6.2016, pp. 1-18.

5 Komerclikums (Commercial Law): LV Likums. Latvijas Vēstnesis, 04.05.2000., Nr. 158/160 $(2069 / 2071)$. 
be technological know-how (whether inventive or not), ideas for new products and markets, commercial information about customers, finance, employment. ${ }^{6}$ Dutch professor Charles Gielen indicates that the meaning of 'trade secret' usually is used interchangeably with the other similarly unclear legal term 'know-how', meaning secret knowledge which can be applied to the production and distribution of products or to the rendering of services by an enterprise, and which leads to a practical result; it can also be transferred. ${ }^{7}$ In one of his articles, professor Charles Gielen also gives further considerations regarding the characteristics of trade secret, given in the paragraph 1, Article 2 of Trade Secret Directive. Some of these considerations deserve additional comments and analysis. Namely, Charles Gielen analyses, inter alia, the requirement c) about " reasonable steps under the circumstances, by the person lawfully in control of the information, to keep it secret" and states that this requirement "involves appropriate legal as well as practical measures, such as setting up appropriate documentation system and procedure, so that later it can be explained to the courts what information is to be protected". ${ }^{8}$ Of course, these and other steps are advisable, however, the infringer should not be released from the liability merely because he, she or it objects that the trade secret holder has not carried out all the reasonable steps, which could have been completed. Moreover, as it is validly suggested by Portuguese legal scholar and practitioner Nuno Suoesa e Silva, the steps taken for protection must be reasonable and it is not required from the trade secret owner to build a fortress around the secret. ${ }^{9}$ Additionally, it would be appropriate to recollect another article of Charles Gielen, where he refers to one of the doctrines, stating that the secrecy requirement also may be derived from the circumstances. ${ }^{10}$ This doctrine is particularly well applicable towards the high-positioned employees of the trade secret holders, such as CEOs, who have a particular duty of care towards the affairs of the company (inter alia, in deciding what kind of measures shall be taken to properly protect the trade secrets) and, therefore, it is important to note that the requirement of point c), paragraph 1, Article 2 of Trade Secret Directive may not be interpreted in the way that the requirement of reasonable steps to be taken by trade secret holder would release the infringer, a person or an entity involved in the infringement of the trade secret, if he, she or it has reasonable grounds to consider that the respective information is a trade secret and should not be disclosed to other persons.

6 Cornish W., Llewelyn D. Intellectual Property: Patents, Copyright, Trade Marks and Allied Rights. Sixth Edition. London: Sweet \& Maxwell, 2007, p. 10.

7 Gielen Ch. The Netherlands. Trade Secrets Law Around the World. Ed. Mel Jager, 2014, p. 4. Available at: http://charlesgielen.com/doc/Trade_Secrets_Law_The_Netherlands_2014.pdf[last viewed April 14, 2019].

8 Gielen Ch. The New European Regime on the Protection of Trade Secrets (Nov. 2018), p. 4. Available at: http://charlesgielen.com/doc/THE_NEW_EUROPEAN_REGIME_ON_THE_ PROTECTION_OF_TRADE_SECRETS.pdf [last viewed April 14, 2019].

9 Suosa e Silva N. What excactly is the trade secret under the proposed directive? Journal of Intellectual Property Law \& Practice, Volume 9, Issue 11, November 2014, Oxford: Oxford University Press, p. 931.

10 Gielen Ch. The Netherlands. Trade Secrets Law Around the World. Ed. Mel Jager, 2014, p. 5. Available at: http://charlesgielen.com/doc/Trade_Secrets_Law_The_Netherlands_2014.pdf[last viewed April $14,2019]$. 
One more notable, descriptive, but at the same time quite comprehensive definition is found in sub-paragraph $(3) \lessgtr 1839$ of USA Economic Espionage Act: "the term "trade secret" means all forms and types of financial, business, scientific, technical, economic, or engineering information, including patterns, plans, compilations, program devices, formulas, designs, prototypes, techniques, processes, programs, or codes, whether tangible or intangible, and whether or how stored, compiled, or memorialized physically, electronically, graphically, photographically or in writing, if (A) the owner thereof have taken reasonable measures to keep such information secret, (B) the information derives independent economic value, actual or potential, from not being generally known to, and not being readily ascertainable through proper means, by the public". ${ }^{11}$

Although the trade secret may encompass various types of secret information, it is important to emphasize that the trade secret may be treated as the property, or to be more precise, intellectual property. ${ }^{12}$ The trade secret shall be distinguished from patents and other forms of intellectual property. Legal doctrine provides several differences between trade secrets and other forms of intellectual property. For instance, unlike a patent, trade secret information need not be unique, novel, or non-obvious to be protected, it even need not be original, allowing for the protection of items like names and phone numbers that would not be protected under copyright. Also, unlike patents and trademarks, trade secret laws allow for the protection of identical information, if two parties independently discover such information. Unlike a patent, a trade secret does not have to be absolutely secret to be a trade secret. ${ }^{13}$ It is interesting to add that quite often trade secret protection is chosen over patent protection, even when the latter is available, because the trade secrets can be everlasting, are apparently cheaper and faster to protect, and do not (obviously) require disclosure. ${ }^{14}$

As the property, trade secret may be sold and alienated by other means. ${ }^{15}$ Also, even without the alienation, the disclosure of the trade secret may be the subject matter (or one of the subject matters) in, for instance, the franchise or licensing agreement. However, nearly everything, which can be alienated, may come into the other person's property by illegal means. It is true also regarding the trade secrets, which may even face a so-called trade secret piracy, ${ }^{16}$ or economic espionage.

11 Economic Espionage Act of 1996: USA Statute. Available at: https://www.govinfo.gov/content/pkg/ PLAW-104publ294/pdf/PLAW-104publ294.pdf [last viewed on April 15, 2019].

12 Gielen Ch. The New European Regime on the Protection of Trade Secrets, p. 2. Available at: http:// charlesgielen.com/doc/THE_NEW_EUROPEAN_REGIME_ON_THE_PROTECTION_OF_ TRADE_SECRETS.pdf [last viewed Āpril 14, 2019].

13 Pacini C. J., Placid R., Wright-Isak Ch. Fighting economic espionage with trade secret laws. International Journal of Law and Management, Vol. 50, Issue 3, 2008, pp. 123, 124.

${ }_{14}$ Suosa e Silva N. What excactly is the trade secret under the proposed directive? Journal of Intellectual Property Law \& Practice, Volume 9, Issue 11, November 2014, Oxford: Oxford University Press, p. 931.

15 Nims H. D. Law of Unfair Competition and Trade-Marks. New York: Baker, Voorhis and Company, 1917, p. 296

16 Archer K. Trade Secret Piracy: Fending Off Treasure Hunters. Available at: https://www.lexisnexis. $\mathrm{com} /$ communities/corporatecounselnewsletter/b/newsletter/archive/2014/11/01/trade-secretpiracy-fending-off-treasure-hunters.aspx [last viewed April 14, 2019]. 
Both the paragraph 2, Article 2 of the Trade Secret Directive and paragraph 2, Article 2 of the Business Secret Protection Act refers to the trade secret holder designating any natural or legal person lawfully controlling the trade secret. It is important to stress that the trade secret holder is not necessarily a merchant or a commercial entity; he, she or it may be an inventor, a person with future business ideas, not yet commenced as commercial activities, or a scientific institute, namely, everyone, who has invented some information, which is secret and has some commercial value or has acquired it from another person by lawful means.

\section{Pre-contractual liability regarding unauthorized use of trade secrets}

Trade secret holder may face a situation where he, she or it is required at least to some extent to disclose the trade secret to another person or entity during the pre-contractual negotiations concerning any future contract, necessary, for instance, to put the trade secret into commercial operation and obtain the necessary funding, or expand the production of the respective product or rendering the services related to the trade secret. Such situations may involve the risk that the other person or entity may decide to use the acquired trade secret for his/her/its own purposes or hand it over to someone else without a proper authorisation by the trade secret holder. In order to avoid such risk, the trade secret holder should insist on concluding the respective confidentiality agreement with the other person or entity, forbidding such action. However, should the trade secret holder be left without any legal protection, if, due to any reason, such an agreement has not been concluded?

The affirmative answer to this question probably should not be supported. Doctrinal documents, such as Principles of European Contract Law, Article 2:302 suggests the duty of the other party not to disclose and not to use confidential information received from the other party. However, despite the fact that notable Latvian legal scholars, such as associate professor Jānis Kārkliņ̌̌ have suggested inclusion of a similar provision in Latvian law, ${ }^{17}$ nevertheless, it has not been done. Business Secrets Act also lacks such provision.

One may argue that maybe the duty not to disclose the trade secrets received from the other party during pre-contractual negotiations, and not to use these trade secrets by that party may be derived from some general principle, for instance, the principle of good faith, set down in the Article 1 of the Civil Law. ${ }^{18}$ At a first glance, such suggestion may seem to be reasonable, as, for instance, Dutch law stipulates that if the negotiation does not result in the agreement and either of the parties makes use of the information acquired during the negotiations, this violates the duty of good faith that governs the special legal relationship between the parties involved in the negotiations. ${ }^{19}$

17 Kārklinšs J. Latvijas līgumtiesību modernizācijas galvenie virzieni (Main Modernization Directions of the Latvian Contract Law). Promocijas darbs. Rigga: Latvijas Universitāte, 2006, 108. lpp.

18 Latvijas Republikas Civillikums (Civil Law): LV Likums. Valdības Vēstnesis, 20.02.1937., Nr. 41.

19 Gielen Ch. The Netherlands. Trade Secrets Law Around the World. Ed. Mel Jager, 2014, p. 4. Available at: http://charlesgielen.com/doc/Trade_Secrets_Law_The_Netherlands_2014.pdf [last viewed April 14, 2019]. 
However, such conclusion in the context of Latvian law is disputable. As it has been indicated by legal practitioner Mr. Mìrons Krons soon after Latvian Civil Law's entry into force in 1937, the principle of good faith is a tool for interpretation of provisions of law and contracts, and it does not itself impose any duties or obligations upon the persons or entities. ${ }^{20}$ Likewise, in the $21^{\text {st }}$ century Latvian legal professor Kaspars Balodis arrived at a similar conclusion, observing that Article 1 of the Civil Law does not authorise the court to invent the provisions of law, which are not set down by the legislator. ${ }^{21}$ Therefore, it can be concluded that the principle of good faith in Latvian law and Article 1 of the Civil Law does not ensure a sufficient protection of trade secret holders against unauthorized disclosure or use of trade secrets, disclosed to the other persons or entities during pre-contractual negotiations. In order to provide such protection, the author suggests including a provision - at least in the Business Secret Protection Act - stating that the person or entity, to whom the trade secret is disclosed during the pre-contractual negotiations, is not allowed to disclose this trade secret to another person or entity or to use this trade secret by that person or entity without a proper permission from the trade secret holder, even if the respective agreement has not been concluded.

\section{Trade secret presumption}

As it was mentioned already in the section 1 above, the trade secret owner or another holder is required to take reasonable steps to keep the trade secret confidential. These reasonable steps must protect the trade secrets against various risks, inter alia, against the disclosure by former and current employees. As it was emphasized by the Latvian Supreme Court, the true level protection of trade secret does depend on the human who accesses this trade secret via computer or otherwise, and neither the contract, nor other means cannot entirely eliminate the risk of trade secret disclosure. ${ }^{22}$ However, one of the theories in psychology - the so-called agency theory, suggests that many individuals, left to their own devices, will pursue their own interests and therefore the organisations striving to protect trade secrets should assume that their employees may divulge their trade secrets in return for some kind of payment or other benefit. ${ }^{23}$ Lack of employees' (current or former) discretion may be treated as one of

20 Krons M. Civillikuma pirmais pants. Laba ticība kā tiesiskās rīcỉbas kritērijs (The First Article of Civil Law. Good Faith as the Criteria of Legally Relevant Actions). Tieslietu Ministrijas Vēstnesis, 1937., Nr. 2, 270.-301. lpp. Pārpublicēts: Jurista Vārds, 2010. gada 21. decembris, Nr. 51 (646).

${ }^{21}$ Balodis K. Labas ticíbas princips mūsdienu Latvijas civiltiesībās (The Principle of Good Faith in contemporary Latvian Civil Law). III.nodaļa. Jurista Vārds, 2002. gada 3. decembris, Nr. 24 (257).

22 Latvijas Republikas Augstākās tiesas Senāta Administratīvo lietu departamenta 2010. gada 17. maija spriedums lietā Nr. SKA-168/2010 (Judgement of the Department of the Administrative Cases of the Senate of the Supreme Court of the Republic of Latvia in case No. SKA - 168/2010 from 17 May, 2010), [8] punkts 4. lpp.

23 Hannah D. R. An Investigation of the Effects of Trade Secret Protection Procedures and Psychological Contract Violations on Employees' Tendencies to Divulge Trade Secrets. Doctoral Dissertation. The University of Texas at Austin, 2000, p. 4. 
the most serious internal risks of the trade secret protection. ${ }^{24}$ Therefore, the trade secret owner should apply reasonable measures in order to prevent the situations when the former or current employees would disclose the trade secrets. Regarding this risk, it is worth to add, that at least the U.S. law provides the doctrine on inevitable disclosure, which means that, when an employee leaves a business for similar position with a competitor, the business claims that the employee in the performance of his/ her new job duties will inevitably use or disclose the trade secrets that are stored in the employee's memory. ${ }^{25}$ The proper measure against such inevitable disclosure is the noncompetition agreement, which is available also pursuant to the Article 84 of the Latvian Labour Law and allows to limit the former employee's entry into employment by competitor or starting his/her own competing business up to the period of two years. ${ }^{26}$ Other measures may include concluding of a confidentiality and non-disclosure agreement, limitation of access to the trade secrets by the personnel not required to access these trade secrets in order to perform their duties, conducting the exit interview with the employee leaving his/her position, when, inter alia, he/she could be reminded about the duty to keep the learned trade secrets confidential and to refrain from using them for his or her own benefit, as well as advising employees of existence of the trade secret. ${ }^{27}$ Regarding the last measure, one may ask to what extent the employer should be specific in advising the employees that the particular information is a trade secret. Should the employer label all such information explicitly as a trade secret, but if he, she or it has failed to attach such a label to the item in question, does the employee have to treat this information as a trade secret and is he or she not obliged to keep it confidential? The author could hardly agree to that, since the employee also owes the duty of loyalty to the employer and must apply reasonable level of care in his or her actions. However, as the reasonable balance between the interests of the employer to avoid application of cumbersome and excessive measures to keep the trade secret confidential, as, for instance, labelling each device or data containing trade secret, and to receive the protection of his, her or its trade secrets, on the one hand, and the interests of the employee to be aware, which information / material constitutes the trade secret, the author proposes to introduce statutory provisions of the trade secret presumption, for instance, in the Business Secret Protection Act. This presumption would mean the legitimation of a mechanism which is already frequently applied in practice and provides that the employer, by concluding of the agreement, be it labour contract, non-disclosure, or confidentiality agreement or noncompetition agreement, advises the employee that certain information, which shall be treated as the commercial secret, for example, calculations of the prices, any lists or databases of the clients, instructions on technology, methods of manufacturing products, etc. Hence,

24 Saias M. A. Unlawful acquisition of trade secrets by cyber theft: between the Proposed Directive on Trade Secrets and the Directive on Cyber Attacks. Journal of Intellectual Property Law \& Practice, Volume 9, Issue 9, September 2014, Oxford: Oxford University Press, p. 722.

25 Aaron Sh. Using the History of Noncompetition Agreements to Guide the Future of Inevitable Disclosure Doctrine. Lewis \& Clark Law Review, Vol. 17:4, 2014, p. 1198.

26 Darba likums (Labour Law): LV Likums. Latvijas Vēstnesis, 2001. gada 6. jūlijs, Nr. 105 (2492).

27 Pacini C. J., Placid R., Wright-Isak Ch. Fighting economic espionage with trade secret laws. International Journal of Law and Management, Vol. 50, Issue 3, p. 124, 125. 
the employer advises the employee on trade secrets not by particular labelling of all the data and information sources, but by marking certain areas of information. In such case, all the information falling within a particular area is presumed to be trade secret, unless it is legally available or known to the public. The duty to prove that a particular information is legally available or known to the public shall lie with the employee.

\section{Specifics of causality and burden of proof in cases concerning misuse of trade secrets}

The starting point for assessing the causation of regular tort cases are but for (conditio sine qua non - Lat.) test, yielding the answer to the question, whether the negative consequences would arise, if a certain wrongful deed were absent. ${ }^{28}$ This method is useful in cases where certain potential cause or causes should be examined and the potential cause or causes basically are of technical character - for instance, the question is, whether the collision of cars would still occur, if the defendant were to start applying the brakes 20 metres before the point where he actually started braking, or whether the substance still could explode, if the defendant were to have transported it in a different manner. However, this is not how the question of causality usually could be evaluated in claims regarding unauthorized disclosure or use of trade secrets. Moreover, in cases where the potential unauthorized disclosure or use of trade secrets is evaluated, quite often the question is also whether there actually appeared the disclosure or use of trade secrets. In this respect, this category of cases is similar to the private antitrust proceedings. One of the issues regarding the causation and evidence in general in private antitrust proceedings refers to the so-called informational asymmetry, when the infringer has much more information than the person who has suffered from infringement and infliction of damage. ${ }^{29}$ Similarly, the person or entity whose trade secrets have been disclosed and/or used without the authorization, in most of the cases would have no certain information, how exactly the disclosure took place and in what way the trade secrets were disclosed. Therefore, the plaintiff most likely would have to rely on indirect evidence, just as in the cases regarding the breach of the competition law, as it was validly emphasized by the Latvian Supreme Court noting that it shall not be expected that the infringer leaves direct and explicit evidence, therefore, the existence and the substance of the infringement must be assessed basically according to the indirect evidence. ${ }^{30}$ Moreover, as the European Court of Justice has ruled regarding violations of the competition law, such violation is normally a result of several combined factors which, taken separately,

28 Strazdiņš G̣. Ieskats cēloniskā sakara vērtēšanas pamatos (Overview of the Basic Aspects of Examining the Causality). Jurista Vārds, 02.05.2017., Nr. 19 (973), 18.-25. lpp.

29 Abele H. A., Kodek G. E., Schaefer G. K. Proving Causation in Antitrust Cases. Journal of Competition Law \& Economics, Volume 7, Issue 4. Oxford, Oxford University Press: December 2011, p. 851.

30 Latvijas Republikas Augstākās tiesas Senāta Administratīvo lietu departamenta 2010. gada 17. maija spriedums lietā Nr. SKA - 168/2010 (Judgement of the Department of the Administrative Cases of the Senate of the Supreme Court of the Republic of Latvia in case No. SKA - 168/2010 from 17 May, 2010) 
are not necessarily decisive. ${ }^{31}$ Important and simultaneously interesting remark on assessment of causality was made in another case dealing with the compensation of damages for the unauthorised disclosure and use of the trade secret. Namely, it was set down that, in order to assess the causation, it shall be evaluated as to whether the former employees would start their own competing business without the knowledge of the significant amount of the trade secrets of the plaintiff. ${ }^{32}$ Therefore, the court was invited to accept the use and assessment of not only certain and obvious facts, but also some hypotheses.

In author's opinion, such approach should be treated as reasonable, because, as already mentioned, the plaintiff most likely will lack certain information, how his, her or its trade secrets were disclosed and use and argumentation of the causality with the reasonable hypothesis might be the only accessible option. However, in order to better assess such hypothesis, the author suggests to apply the so-called adequacy theory (Adäquanztheorie - De.), which, inter alia, provides the evaluation whether the cause was adequate to create the damage (or other violation). ${ }^{33}$ Therefore, in the context of cases involving unauthorized disclosure or use of trade secrets, the question, which is to be assessed in order to achieve the answer on causality, namely, whether the unauthorized disclosure or use of trade secrets has arisen, is the question, whether a certain sum of circumstances (for instance, substantial increase of the sales amounts of the defendant, move of several former clients or employees of the plaintiff to the defendant, developing of the new projects by the defendant, strengthening his competition with the plaintiff, etc.) along with the fact which may have given the reason to suspect a possible misuse of trade secrets, for instance, move of a high-ranking former manager of plaintiff to the defendant, could be treated as adequate consequences of the said misuse of plaintiff's trade secret? If the plaintiff has successfully proved such hypothesis, the defendant shall prove that there are other reasonable explanations of the existing situation (defendant's implementation of his, her, its own unique systems, etc.), similarly to the approach how the burden of proof is distributed in Germany in antitrust private enforcement cases, where the defendant must give clarification to dissipate the concerns regarding abuse of dominant position. ${ }^{34}$

Last but not least, as it is provided in the German law, the causality matters are dealing not only with the question whether the violation or breach could be found (for instance, the misuse of trade secrets, but also the extent of liability, inter alia, the amount of damage. ${ }^{35}$ This aspect will be examined in the next and final chapter of this article.

31 Judgment of the European Court of Justice in joined cases C-295/04 to C-298/04 Manfredi, para. 43.

32 Latvijas Republikas Augstākās tiesas Civillietu departamenta 2015. gada 27. februāra spriedums lietā Nr. SKC-0008/2015 (Judgement of the Department of the Civil Cases of the Supreme Court of the Republic of Latvia in case No. SKC-0008/2015 from 27 February, 2015), [9.11] punkts, 12. lpp.

33 v. Dam C. European Tort Law. $2^{\text {nd }}$ ed. Oxford: Oxford University Press, 2013, p. 312.

34 Woods D., Sinclair A., Ashton D. Private enforcement of Community competition law: modernisation and the road ahead. Competition Policy Newsletter, No. 2, Summer, 2004, p. 35.

35 v. Dam C. European Tort Law. Second Edition. Oxford: Oxford University Press, 2013, p. 312. 


\section{Assessment of the amount of damages in the cases concerning the misuse of trade secrets}

Generally, there are four concepts for calculating the damages in case of trade secret infringement. The first one is the lost profits, which, in essence, are actual damages in the form of profits that would have been made by the trade secret holder, had there been no misuse. The second one is unjust enrichment, which is deemed to be made by the defendant as a consequence of misusing trade secrets. The third one is reasonable royalty, which could be received for licensing of the misused trade secret. The fourth one is the damage calculation according to the full market value. ${ }^{36}$ All these methods are compatible with Article 14 of the Trade Secret Directive, stating the approaches to calculation of the damages incurred by misuse of trade secrets, and hence should be available also in Latvia. However, the practical prospects for application of these methods in Latvia are different for each method.

As regards the calculation of damages on the basis of lost profits, it has to be said that Article 1772 Latvian Civil Law allows and even explicitly mentions the possibility to include the lost profits in the calculation of damages. However, Article 1787 of Latvian Civil Law requires a rather high standard for the certainty of lost profits to be proved. Namely, this Article provides that in order to calculate the lost profits not only the possibilities should be taken into account, but it has to be proved to the level of reasonable trustworthiness that such a loss has occurred, directly or indirectly arising from the wrongful deed or inactivity, which caused such damages. If the plaintiff has not yet commercialized his, her, its trade secret, or the trade secret relates to the information, the value of which could be difficult to calculate directly, for instance, the information about the remuneration system of the employees, the necessity to prove the damages to the required level of trustworthiness may appear to be an impossible task for the plaintiff. Similar issues may appear regarding the calculation of damages on the basis of reasonable royalty payments or full market value. Under the circumstances, if the trade secret was never licensed or by its nature it most likely cannot be distinguished separately from other assets (for instance, information about the remuneration system to the employees), the court may dismiss such attempts to calculate the trade secret breach damages.

Hence, the only realistic option may remain the calculation of damages pursuant to the unfair enrichment of the defendant. However, considering how such attempts to calculate the damages incurred by the misuse of intellectual property have so far been treated by the Latvian courts, the results are not encouraging. For instance, in one case, which was filed regarding the misuse of industrial design, the court, despite finding that the defendants have violated the exclusive rights of the plaintiff, dismissed the claim for the compensation of damages, the amount of which was calculated according to the amount specified in the preliminary calculation and the invoice for the counterfeit products. In court's opinion, the plaintiff had failed to prove that he really had

36 Wilson B. J., Gold J. G., Verkuil C. R., Ortiz D. X. Calculating Trade Secret Damages: Overview and Defense Strategies. AIPLA 2011 Spring Meeting, pp. 4, 5. Available at: https://media2.mofo.com/ documents/110500tradesecretdamages.pdf [last viewed April 14, 2019]. 
suffered the damages in such amount. ${ }^{37}$ In fact, the court applied the standard of proof, necessary to substantiate the damages, which had already occurred (for instance, damages to material property) to the substantiation of the unfair enrichment and, hence, had mixed together two different things. Although this particular judgment has come into effect, the findings thereof cannot be supported. As it is validly emphasized by the Latvian legal scholar and practitioner Dr. Erlens Kalninšs, it is not correct to deem that the primary purpose of the compensation of damages is merely to restore the original material situation of the person, who has suffered the damages. Therefore, sometimes the material situation of the person, who has suffered the damages shall be restored to the level which exceeds the situation at the moment of infringement. ${ }^{38}$ In the context of such considerations, the author would like to suggest to use the adequacy theory also for the calculation of damages incurred by misuse of trade secret. If, as suggested in the previous chapter of this article, the plaintiff has successfully proved that a certain sum of circumstances together with the fact which may give the reason to believe in possible misuse of trade secrets are adequate as the consequences of misuse of plaintiff's trade secret, the amount of damages to be awarded to the plaintiff, could be calculated as an adequate value of the economic benefit acquired by the defendant as a result of misusing plaintiff's trade secret.

\section{Conclusions}

To sum up, the author would like to emphasize the following conclusions:

1. One of the situations, when a person or an entity may access trade secrets of another is a negotiation procedure with a view of potential conclusion of the contract in the future. In order to ensure that the trade secrets accessed during such precontractual liability would not be misused, the law must include provisions on pre-contractual liability, as some legal scholars have already proposed. However, these provisions should be applicable not only to the merchants, but to all persons or entities.

2. Another point of risk concerning unauthorised access to the trade secrets is the case, when a former employee of one entity become an employee of another competing entity and, hence, discloses the trade secrets of his former employer to the new one. Such situations may also appear, if the employee fails to discern a certain information as a trade secret, yet, in fact, it is. In order to minimise such situations, the law must provide for the presumption of trade secret to be applicable to certain categories of information, if the employer has explicitly in writing informed the employee about the application of this presumption and advised that these

37 Rīgas apgabaltiesas Civillietu tiesu kolégijas 2015. gada 12. marta spriedums lietā Nr. C04153414 (Judgement of Civil Collegium of Riga Regional Court in case No.C04153414 from 12 March, 2015), [9.10] punkts 20. lpp.

38 Kalniņš E. Jēdziena "zaudējumi” izpratnes tālākas attīstīšanas nepieciešamība (The Necessity of Further Development in the Understanding of the Term "Damages"). Latvijas Republikas Satversmei - 95. Latvijas Universitātes 75. zinātniskās konferences rakstu krājums. Rìga: LU Akadēmiskais apgāds, 2017, 58. lpp. 
categories of information will be treated as trade secret, unless they are legally available or known to the public. The duty to prove that a particular information is legally available or known to the public should lie with the employee.

3. In order to improve the prospects of the person or entity, whose trade secret has been accessed without a proper authorisation, to claim the damages from the person or entity who has accessed these trade secrets, the causality regarding the fact of possible misuse of the trade secrets and the amount of damages must be assessed from the perspective of adequacy theory.

4. In order to improve the prospects of the person or entity, whose trade secret has been accessed without a proper authorisation, the amount of damages to be awarded to the plaintiff could be calculated as an adequate value of the economic benefit acquired by the defendant through misuse of plaintiff's trade secret.

\section{BIBLIOGRAPHY}

\section{Literature}

1. Aaron Sh. Using the History of Noncompetition Agreements to Guide the Future of Inevitable Disclosure Doctrine. Lewis \& Clark Law Review, Vol. 17:4, 2014.

2. Abele H. A., Kodek G. E., Schaefer G. K. Proving Causation in Antitrust Cases. Journal of Competition Law \& Economics, Volume 7, Issue 4. Oxford: Oxford University Press: December 2011.

3. Archer K. Trade Secret Piracy: Fending Off Treasure Hunters. Available at: https://www.lexisnexis.com/communities/corporatecounselnewsletter/b/newsletter/archive/2014/11/01/ trade-secret-piracy-fending-off-treasure-hunters.aspx [last viewed April 14, 2019].

4. Balodis K. Labas ticības princips mūsdienu Latvijas civiltiesībās (The Principle of Good Faith in contemporary Latvian Civil Law). III. nodaļa. Jurista Vārds, 2002. gada 3. decembris, Nr. 24 (257).

5. Cornish W., Llewelyn D. Intellectual Property: Patents, Copyright, Trade Marks and Allied Rights. Sixth Edition. London: Sweet \& Maxwell, 2007.

6. v. Dam C. European Tort Law. Second Edition. Oxford: Oxford University Press, 2013.

7. Gielen Ch. The Netherlands. Trade Secrets Law Around the World. Ed. Mel Jager, 2014, p. 4. Available at: http://charlesgielen.com/doc/Trade_Secrets_Law_The_Netherlands_2014.pdf [last viewed April 14, 2019].

8. Gielen Ch. The New European Regime on the Protection of Trade Secrets (Nov. 2018), p. 4. Available at: http://charlesgielen.com/doc/THE_NEW_EUROPEAN_REGIME_ON_ THE_PROTECTION_OF_TRADE_SECRETS.pdf [last viewed April 14, 2019].

9. Hannah D. R. An Investigation of the Effects of Trade Secret Protection Procedures and Psychological Contract Violations on Employees' Tendencies to Divulge Trade Secrets. Doctoral Dissertation. The University of Texas at Austin, 2000.

10. Kalniņš E. Jēdziena "zaudējumi” izpratnes tālākas attīstī̌̌anas nepieciešamība (The Necessity of Further Development in the Understanding of the Term "Damages"). Latvijas Republikas Satversmei - 95. Latvijas Universitātes 75. zinātniskās konferences rakstu krājums. Riga: LU Akadēmiskais apgāds, 2017, 54.-61.lpp.

11. Kārkliņš J. Latvijas līgumtiesību modernizācijas galvenie virzieni (Main Modernization Directions of the Latvian Contract Law). Promocijas darbs. Rigga: Latvijas Universitāte, 2006. 
12. Krons M. Civīllikuma pirmais pants. Laba ticība kā tiesiskās rīcības kritērijs (The First Article of Civil Law. Good Faith as the Criteria of Legally Relevant Actions). Tieslietu Ministrijas Vēstnesis, 1937, Nr. 2, 270.-301. lpp. Pārpublicēts: Jurista Vārds, 2010. gada 21. decembris, Nr. 51 (646).

13. Nims H. D. Law of Unfair Competition and Trade-Marks. New York: Baker, Voorhis and Company, 1917.

14. Pacini C. J., Placid R., Wright-Isak Ch. Fighting economic espionage with trade secret laws. International Journal of Law and Management, Vol. 50, Issue 3, 2008.

15. Saias M. A. Unlawful acquisition of trade secrets by cyber theft: between the Proposed Directive on Trade Secrets and the Directive on Cyber Attacks. Journal of Intellectual Property Law \& Practice, Volume 9, Issue 9, September 2014, Oxford: Oxford University Press.

16. Strazdiņš G̣. Ieskats cēloniskā sakara vērtēšanas pamatos (Overview of the Basic Aspects of Examining the Causality). Jurista Vārds, 02.05.2017., Nr. 19 (973).

17. Suosa e Silva N. What exactly is the trade secret under the proposed directive? Journal of Intellectual Property Law \& Practice, Volume 9, Issue 11, November 2014, Oxford: Oxford University Press.

18. Wilson B. J., Gold J. G., Verkuil C. R., Ortiz D. X. Calculating Trade Secret Damages: Overview and Defense Strategies. AIPLA 2011 Spring Meeting. Available at: https://media2.mofo.com/ documents/110500tradesecretdamages.pdf [last viewed April 14, 2019].

19. Woods D., Sinclair A., Ashton D. Private enforcement of Community competition law: modernisation and the road ahead. Competition Policy Newsletter, No. 2, Summer 2004.

\section{Normative acts}

20. Agreement on Trade-Related Aspects of Intellectual Property Rights. Annex 1C of the Marrakesh Agreement Establishing the World Trade Organisation, signed on 15 April, 1994. International Agreement.

21. Directive (EU) 2016/943 of the European Parliament and of the Council of 8 June 2016 on the protection of undisclosed know-how and business information (trade secrets) against their unlawful acquisition, use and disclosure. OJ L 157, 15.6.2016, pp. 1-18.

22. Latvijas Republikas Civillikums (The Civil Law of the Republic of Latvia): LV Likums. Valdibas Vēstnesis, 20.02.1937., Nr. 41.

23. Economic Espionage Act of 1996: USA Statute. Available at https://www.govinfo.gov/content/ pkg/PLAW-104publ294/pdf/PLAW-104publ294.pdf [last viewed April 15, 2019].

24. Komerclikums (Commercial Law): LV Likums. Latvijas Vēstnesis, 04.05.2000., Nr. 158/160 (2069/2071).

25. Darba likums (Labour Law): LV Likums. Latvijas Vēstnesis, 2001. gada 6. jūlijs, Nr. 105 (2492).

26. Komercnoslēpuma aizsardzības likums ((Business Secret Protection Act): LV Likums. Latvijas Vēstnesis, 14.03.2019., Nr. 52 (6391).

\section{Court practice}

27. Judgment of the European Court of Justice in joined cases C-295/04 to C-298/04 Manfredi.

28. Latvijas Republikas Augstākās tiesas Senāta Administratīvo lietu departamenta 2010. gada 17. maija spriedums lietā Nr. SKA-168/2010 (Judgement of the Department of the Administrative Cases of the Senate of the Supreme Court of the Republic of Latvia in case No. SKA168/2010 from 17 May, 2010). 
29. Latvijas Republikas Augstākās tiesas Civillietu departamenta 2015. gada 27. februāra spriedums lietā Nr. SKC-0008/2015 (Judgement of the Department of the Civil Cases of the Supreme Court of the Republic of Latvia in case No. SKA - 0008/2015 from 27 February, 2015).

30. Rīgas apgabaltiesas Civillietu tiesu kolēgijas 2015. gada 12. marta spriedums lietā Nr. C04153414 (Judgement of Civil Collegium of Riga Regional Court in case No. C04153414 from 12 March, 2015). 